\section{LITA AWARD}

Nominations are sought for the Library and Information Technology Association's Award for Achievement in Library and Information Technology. The award is intended to recognize distinguished leadership, notable development or application of technology, superior accomplishments in research or education, or original contributions to the literature of the field.

The award may be given to an individual or to a small group of individuals working in collaboration. Organized institutions or parts of organized institutions are not eligible.

Nominations for the award may be made by any member of the American Library Association and should be submitted by January 15, 1982, to Hank Epstein, LITA Awards Committee Chairperson, 1992 Lemnos Drive, Costa Mesa, CA 92626.

\section{ACRL Nonprint Media Publications Series}

The ACRL Nonprint Media Publications Editorial Board invites submission of material for inclusion in the ACRL Nonprint Media Publications Series.

Audiocassette programs, slide-tape packages, or videotapes that are of interest to the ACRL membership and deal with such topics as library instruction, personnel management. instructional development, or similar topics, should be sent to Jean W. Farrington, Editor, Van Pelt Library, University of Pennsylvania, Philadelphia, PA 19104. Inquiries about the ACRL Nonprint Media Publications board and its activities may also be directed to the same address.

Richard D. Johnson has been appointed acting editor of Choice magazine and will be on leave from his permanent position as director of libraries at the State University College, Oneonta, New York. He was editor of C\&RL, 1974-80, and program chair for the First National ACRL Conference, Boston, 1978.

\section{Classified Advertising}

Deadlines: Orders for regular classified advertisements must reach the ACRL office on or before the second of the month preceding publication of the issue (e.g. September 2 for the October issue). Late job listings will be accepted on a space-available basis after the second of the month.

Rates: Classified advertisements are $\$ 4.00$ per line for ACRL members, $\$ 5.00$ for others. Late job notices are $\$ 10.00$ per line for members, \$12.00 per line for others. Organizations submitting ads will be charged according to their membership status.

Telephone: All telephone orders should be confirmed by a written order mailed to ACRL headquarters as soon as possible. Orders should be accompanied by a typewritten copy of the ad to be used in proofreading. An additional $\$ 10$ will be charged for ads taken over the phone (except late job notices or display ads).

Guidelines: For ads which list an application deadline, that date must be no sooner than the last day of the month in which the notice appears (e.g., October 31 for the October issue). All job announcements must include a salary figure. Job announcements will be edited to exclude discriminatory references. Applicants should be aware that the terms faculty rank and status vary in meaning among institutions.

JOBLINE: Call (312) 944-6795 for late-breaking job ads for academic and research library positions. A prerecorded summary of positions listed with the service is revised weekly: each Friday a new tape includes all ads received by 1:00 p.m. the previous day. Each listing submitted will be carried on the recording for two weeks. The charge for each two-week listing is $\$ 30$ for ACRL members and $\$ 35$ for non-members

Fast Job Listing Service: A special newsletter for those actively seeking positions. The service lists job postings received at ACRL headquarters four weeks before they appear in C\&RL News, as well as ads which because of narrow application deadlines, will not ap pear in C\&RL News. The cost of a six-month subscription is $\$ 10$ for ACRL members and $\$ 15$ for non-members.

Contact: Classified Advertising Dep't, ACRL, American Library Association, 50 E. Huron St., Chicago, IL 60611; (312) 944-6780.

\section{FOR SALE}

MARV GROADBENT, Box 6, Beltsville, MD 20705. Government Publications. Standing. Subscription, single, or search arders. No prepayment No foreign surcharge. (301) $937-8846$.
BUSINESS FOR SALE. Over 18,000 collections of original book reviews from 1929-1970. Reviews on File, Box 298, Walton, NY 13856.

FOREIGN MICROFORMS. Any foreign microform from anywhere in the world at the foreign list price. Free searching. Monographs and serials. IMDS, 1995 Broadway, NY, NY 10023, (212) 873-2100.

\section{POSITIONS OPEN}

ASSISTANT DIRECTOR FOR PUBLIC SERVICES. University of Miami Libraries. Administers and coordinates the activities of the Public Service Division; participates with other members of the Library administration in development of library policy. Qualifications: MLS from an ALA-accredited school, at least seven years' related experience in a large academic library, strong leadership qualities, ability to work effectively with teaching faculty. Tweive month faculty appointment. Salary dependent on qualifications, with a starting range of $\$ 23,000-\$ 28,000$. Position available June 1,1982 . Benefits include moving allowance, tuition remission, noncontributory TIAA/CREF, one month vacation and partially paid insurance plan. To ensure consideration, please send before January 8, 1982, a letter of application, resume and the names of three references to Ronald P. Naylor, Assistant Director for Administrative Services, University of Miami Library, P.O. Box 248214. Coral Gables, FL 33124. Interviews may be arranged at Al A Midwinter. The University of Miami is an EO/AA employer.

ASSISTANT LIBRARIAN, Catalog Department, Law Library, Responsibilities: original cataloging of monographs and serials, using AACR-2, LCSH, and RLIN: maintenance of catalog department tools, administrative support for cataloging operations, training and revision of support staff catalogers; supervision of department in absence of department head. Requirements: MLS from an accredited school; one to two years library experience, preferably in cataloging or serials, in an academic or law library. Knowledge of law materials and/or serials desirable. Salary: $\$ 13,500$ up, depending on background and experience. Available January 1,1982 Apply to Carolyn A. Pyhtila, Personnel Director, 235 Olin Library Cornell University, Ithaca, NY 14853. Cornell University is an equal-opportunity/affirmative-action employer.

ASSISTANT OR ASSOCIATE PROFESSOR (tenure-track) for August 1982, information science. PH.D. In library science or related field completed or near completion. Understanding of applications of automation to libraries required. At least two years of work ex- 


\section{DIRECTOR, LEARNING RESOURCE CENTER}

Responsible for all areas of Center's operation including reference and circulation services to academic community, acquisition and cataloging of all print and non-print materials, budget monitoring, collection building, and staff supervision.

MLS from accredited School of Library and Information Science plus two or more years of successful administrative and supervisory experience required. 12-month contract starting June 1, 1982. Salary in mid-teens to low twenties, dependent upon qualifications and experience. Send resume to:

\section{Director of Personnel Centenary College 400 Jefferson Street Hackettstown, NJ 07840} by February 1, 1982.

An Equal Opportunity-Affirmative Action Employer.

perience at the professional level and some teaching experience preferred. Consideration given to potential for research and publica tion. Teaching load: two courses each semester. Additional responsibilities: student advising, committee work, supervision of field experience. Minimum salary: \$21,000. Summer school teaching op tional at $1 / 6$ academic year salary. TIAA Blue Cross-Blue Shield Letter of application, resume, and three letters of reference by February 12, 1982, to: Mary Kingsbury, School of Library Science Manning Hall 026-A, University of North Carolina, Chapel Hill, NC 27514. An equal-opportunity/affirmative-action employer

ASSOCIATE UNIVERSITY LIBRARIAN FOR PUBLIC SERVICES. Responsible for coordinating activites of public service departments of Graduate Library, Undergraduate Library, and six science libraries attached to acacemic departments. ALA-accredited MLS and at least five years' supervisory experience in public services in a research library required. Minimum salary $\$ 30,000$, plus standard State benefits. Send resume and names of three references by February 1, 198? to Laura Warren, Administrative Offices Wilson Library 024A, University of North Carolina, Chapel Hill, NC 27514 An equal-opportunity/affirmative-action employer. Minority candidates are encouraged to apply.

CATALOG LIBRARIAN for original cataloging and classification catalog maintenance, and to assist with conversion to computerbased systems. Non-tenure position, some reference. Must have MLS from ALA-accredited library school. Salary based on training and experıence minimum $\$ 15,488$ annual. Send letter of application, and three letters of recommendation to: Charles H. Baumann University Librarian, Eastern Washington University, Cheney, WA 99004 , by January 4,1982. EWU is an affirmative-action/equalopportunity employer.

CATALOGER. New position. Will work with two (2) other professional catalogers. Responsibilities include original and copy cataloging (primarily of monographs) in all subject areas, filing work, and revision. Must possess a library degree from an ALA-accredited school. Requires working knowledge of AACR-2, OCLC, and LC classification and subject headings. This person is expected to work evening and weekend hours according to OCLC schedule. It is anticipated that the position will be permanent until the completion of our reclassification project, at which time one cataloger may be transferred to another department within the library. Fringe benefits include faculty status, 12-month contract. State Teachers' Retirement System, 2-week vacation. Minimum salary: $\$ 16.889$, dependent upon experience and qualifications. Submit letter of application and current resume to: Richard H. Reid, Director of Library Services, Frazar Memorial Library, McNeese State University, Lake Charles, Louisiana 70609, before January 1, 1982. An equalopportunity/affirmative-action employer.
DEAN OF THE COLLEGE OF LIBRARY AND INFORMATION SER VICES, University of Maryland. Reporting to the Provost of the Division of Human and Community Resources, the Dean is responsible for administering all aspects of the College including program de velopment, budget, academic planning, and personnel matters Works closely with the College faculty committees in establishing academic policy and procedures. Serves as the official spokesperson on behalf of the College to other units and agencies within and outside the University. Encourages and stimulates improvement in the activities of the faculty and staff in teaching, research, and service, and also encourages and supports proposals for external fund ing of projects and research. Qualifications: applicants must hold a doctorate in library, information science, or a related field. Knowledge of data base management, machine applications, and general information technology is desirable. Prior administrative experience, successful teaching, and evidence of scholarly recognition and production are important. Effective date: July 1, 1982. Rank and salary: twelve month appointment. Candicate must qualify for a tenured faculty appointment. Salary commensurate with experience and qualifications, $\$ 45,000$ plus. The University and the College of Library and Information Services has the only degree programs (MLS and Ph.D.) in its specialties in the State. Nominations or applications with current resume and the names of at least 3 references should be sent to: John Burt, Chairman of Search Committee for Dean of the College of Library and Information Services, PERH Building, University of Maryland, College Park, MD 20742. Applications and nominations should be received no later than December 28,1981 . The University of Maryland is an equal opportunity employer

HEAD LIBRARIAN/DIRECTOR OF LEARNING RESOURCES, Liberal arts college of 2,600 with 150,000 volumes, budget of $\$ 225,000,5$ professional staff and learning resources center, Qualifications: ALA/MLS, 5 years management experience in an academic library preferred; ability to communicate effectively with staff, faculty and students. Minimum salary $\$ 20,000$. Send resume, 3 letters of reference to Herbert House, Box 2187. Elon College, Elon College, NC 27244 by January 15, 1982. Equal opportunity employer.

HEAD OF REFERENCE. Supervises all operations of a department consisting of three professionals and one paraprofessional. Reviews and revises department's policies and programs inciuding interlibrary loan, data base searching and bibliographic instruction. Prepares reports, budgets, and statistical data as required. Participates in collection development. OCLC and data base searching preferred. MLS-ALA degree. Four years protessional experience; supervisory experience required. Eleven month appointment, academic rank and status. Salary $\$ 20,000$ negotiable Position available January 1, 1982. Submit application, resume, and three

\section{EDITOR}

\section{Choice Magazine}

Editor for the book review journal Choice, located in Middletown, Connecticut. Responsible for the management, editorial, marketing, advertising, and production activities to produce Choice and related products. Supervises a staff of 20 and administers a budget of $\$ 800,000$. Requires demonstrated managerial ability and experience in college library administration and/or collection development. Publishing or marketing experience desirable. MLS degree. Salary range, $\$ 23,628-\$ 33,708$. 22 days vacation. TIAA/CREF. Liberal benefits.

Send resume or suggestions for potential candidates by January $\mathbf{3 0}$ to:

$$
\begin{gathered}
\text { J. Katzenberger } \\
\text { Personnel Director } \\
\text { American Library Association } \\
50 \text { E. Huron St. } \\
\text { Chicago, IL } 60611
\end{gathered}
$$

An equal opportunity employer M/F 
letters of reference by January 15, 1982, to Ralph Melnick, Acting Director of Library, College of Charleston, Charleston, SC 29424

LIBRARY DIRECTOR. Responsibilities: planning, budgeting, personnel administration, leadership, etc., for library of 500,000 print volumes, professional/clerical staff of 40 . Minimum qualifications: MLS (ALA-accredited) required, doctorate preferred; five years academic library experience, including administration; experience in both reader and technical services preferred. Salary competitive based on experience and qualifications, established within salary administration program. For descriptive materials, send letter of application (deadline: January 29, 1982) to: Provost, Centra Missouri State University, Warrensburg, MO 64093. Equal educa tion and employment opportunity.

LIBRARY FACULTY. (1) Assistant Public Service Librarian. Genera reference, library instruction, online searching, assist with circula tion and $\mid \mathrm{LL}$, training/supervision of student aides. MLS plus 2 years academic reference experience required; knowledge of online searching desirable. (2) Catalog Librarian. Original/copy cataloging in WLN-based department processing 10,000 titles ptr year. MLS knowledge of $L C$, AACR/AACR2, ISBD, MARC required; knowledge of Latin or other Romance language, previous cataloging experi ence preferred. Both positions available after January 1. Permanent appointments with full faculty status, benefits; 12 month contract salary negotiable, $\$ 13,000$ minimum. Send resume and 3 recen. references to: Robert L. Burr, Director, Crosby Library, Gonzaga University, Spokane, WA 99258

LIFE SCIENCES LIBRARIAN. Science-Engineering Library. Re sponsible for collection development in the life sciences, excluding medicine; serves as liaison to life sciences departments, provides reference service including online searching and develops biblio graphic instruction; oversees science-engineering interlibrary loan reserve and inventory operations, participates in developing library research proposals. MLS from an ALA-accredited library school is required. An advanced degree in the life sciences is highly desirable. Position is currently open. An appoinlment will be made in the range of $\$ 15,000-\$ 17,500$, depending on qualifications. Send application including names of references to Lance Query. Person nel Librarian, Northwestern University Library, Evanston, IL 60201 Applications received by December 31 will be considered. An equal-opportunity/affirmative-action employer

ORIENTATION LIBRARIAN. University of Arizond Library. Works under direction of Assistant University Librarian for Public Services in administering, planning developing and evaluating orientation and instruction programs for students, faculty and library staff. Coordinates course-related and other orientation/instruction activities in cooperation with various members or " "3 library staff. Supervises one full-time professional libraicon ard several student assistants who implement a workbook-bascd Library Skills Program required of 4,000 students enrolled in Englisin classes. Requirements include an ALA-accredited library degree, instructional experience in a college or unversity library, demonstratei supervisony abilities, familiarity with educational techniques, superior communication and planning skills, broad knowledge of academic library reference sources and ability to interact effectively with a variety of individu als. Preference given to candidates with at least three years of progressively responsible academic library experience. Position avaiable July 1. 1982. Salary range $\$ 18,000-\$ 23,000$. Faculty status, 12 -month appointment, 22 days vacation, fringe benefits. Send re 5ul,e, including three references to: $W$. David Laird, University Librarian. Main Library, University of Arizona, Tucson, Arizona 85721. Application deadline: January 29, 1982. An equal opportunity/affirmative-action employer.

PUBLIC SERVICES LIBRARIAN. Point Loma College, a Christian liberal arts college owned and operated by the Church of the Nazarene, has an opening April 1, 1982, for a librarian to provide general reference services. Qualifications: MLS from ALA-accredited program, at least one year post MLS experience in reference work bibliographic instruction, online reference searching, academic background in the natural sciences to assist in evaluation and collection building, evidence of Christian commitment and active membership in an evangelical church. Preference is given to members of the Church of the Nazarene. Faculty rank fringe benefits, TIAA/CREF, salary $(\$ 14,000-\$ 20,000)$ commensurate with education and experience. Send resume to: Esther Schandorff, Director of Learning Services, Ryan Library. Point Loma College, 3900 Lomaland Drive. San Diego. CA 92106.

\section{COLUMBIA UNIVERSITY}

\section{East Asian Librarian}

Nominations and applications are invited for the position of East Asian Librarian, Columbia University Libraries, for appointment on or about July 1, 1982

Columbia's East Asian Library is one of the largest and oldest in the nation. A major renovation of the facilities is near completion, and the library will be dedicated as the C.V. Starr East Asian Library. The collections, representing exceptional breadth and depth in the humanities and social sciences, contain over 400,000 volumes principally in Chinese, Japanese, and Korean, but also in Manchu, Mongolian, and Tibetan. In addition, the collections contain a large number of Western Language books and periodicals concerning East Asia. The library's participation in the Research Libraries Group special East Asian development program will provide machine-readable capability for the control of Asian material by 1983. The library has a staff of 11 librarians, 12 support staff, and 8-10 part-time assistants.

The East Asian Librarian, who as director of this distinctive collection will have primary responsibility for administering the service and collection development programs of the library, reports directly to the Vice President and University Librarian. The incumbent will be expected to work closely with the faculty and staff (1) to guide the growth of the collections, (2) to develop and manage distinctive library services in support of the teaching and research needs of Columbia University and (3) to implement programs in various collection development and technical processing activities in cooperation with the Research Libraries Group and other consortia.

Requirements for the position include a strong scholarly background in East Asian studies, demonstrated managerial and leadership capacities, and the ability to engender outside support for the library's programs and collections. An MLS or a Ph.D. in a relevant subject area is desirable. Minimum salary, depending on experience and qualifications, is $\$ 35,000$.

Please submit resume or nomination to East Asian Librarian Search Committee, Box 35, Butler Library, Columbia University Libraries, 535 West 115th Street, New York, NY 10027. Deadline for applications is January 15, 1982. 


\section{DIRECTOR OF LIBRARIES}

\section{University of Nevada, Las Vegas}

The University of Nevada, Las Vegas, invites applications and nominations for a Director of Libraries.

Applicants should possess the MLS (ALA-accredited); a Ph.D. or second masters is desirable. Candidates should present evidence of administrative experience in an academic library, skills in personnel management, and ability to work with campus administration and faculty. Also desired is knowledge of current developments in library technology including computer applications. Responsibilities of the position include the developing of library services in a newly expanded facility, planning, budgeting, and automation. The Director of Libraries serves on the campus Academic Council and answers directly to the Vice President for Academic Affairs. Twelve-month contract with one month's vacation, faculty status, tenure track, and TIAA/CREF. Salary is competitive according to experience and background.

The University of Nevada, Las Vegas has 10,000 students, over 300 full-time faculty, and offers graduate degrees in 23 subject fields. UNLV has many strong programs such as hotel administration, arid land research, life sciences, and anthropology. The library contains approximately 400,000 books, a microfilm collection of 250,000 and subscriptions to 5,000 periodicals. Additional resources include curriculum materials collection and special collections of Nevadiana and gambling. Library materials budget exceeds $\$ 500,000$.

Applications will be received until January 15,1982 . Send letter of nomination or application, resume, and three current professional references to:

\section{Search Committee for Director of Libraries c/o Office of the Vice President for Academic Affairs \\ Flora Dungan Humanities Building \\ University of Nevada, Las Vegas Las Vegas, NV 89154}

UNLV is an Afflrmative Action, Equal Opportunity Employer, M/F.

\begin{abstract}
RARE BOOKS CATALOGER. Duties and responsibilities: under the general direction of the head of the humanities cataloging section in the catalog department, and with the direct counsel of the assistant rare books librarian, the rare books cataloger is responsible for cataloging monographs and other material in the rare books de partment collection; supervises, trains and coordinates rare books department personnel who search or catalog some material with Library of Congress copy; assists in training other special collections personnel who are engaged in cataloging; serves as liaison between the rare books department and the catalog department; serves to ensure the cuality of catalog records by proofreading those representing rare books and special collections materals input into the RLIN system. Qualifications: fifth year degree from an accredited library school, undergraduate or graduate training in the humanities one or two years cataloging experience in rare books and manuscripts, including use of LC classification, subject headings, and rules for the bibliographic description of rare books, good working knowledge of romance languages, especially French and Italian, knowledge of enumerative and descriptive bibliography desirable, working knowledge of MARC II communications format and RL N or OCLC online systems. Closing date: December 30, 1981. Available date: January 1,1982 . Salary: $\$ 13,500$ plus depending on experience. Apply to Carolyn A. Pyhtila, Personnel Director, 235 Olin Library, Cornell University, Ithaca, NY 14853. Cornell University is an equal-opportunity/affirmative-action employer.
\end{abstract}

REFERENCE LIBRARIAN. Search reopened for two entry level pos tions in General Reference. Serve at reference desk perform on line bibliographic searching, participate in library instruction and collections development in assigned discipline. To qualify must have ALA-accredited MLS and be familiar with online searching techniques. Prefer someone with second masters in humanities or social sciences; proficiency in one or more Western European lan guages, German and/or French preferred. Salary $\$ 13,000$. U paid health insurance. TIAA/CREF, 25 days vacation. Additional benefits. By February 12, 1982, send resume naming three references to Winn Margetts, Personnel Officer. University of Utah Libraries, Salt Lake City. Utah 84112 . Interviews, ALA Midwinter in Denver. Positions immediately available but will also consider 1982 graduates AAIEEO employer

REFERENCE LIBRARIAN, for dynamic program of humanities social sciences reference service in an outstanding college library. Qualifications: MLS, strong academic credentials, proven commitment. Previous experience in library instruction, database searching, and government documents preferred, as well as additiona degree in a social science field. Salary: $\$ 15,000$ minimum. Avai! able: February, 1982. Apply by January 5, 1982. Send application, resume, and supporting credentials, including three letters of reference, to: Reference Search Committee, Oberlin College Library. Oberlin, Ohio 44074. AA/EOE.

REFERENCE LIBRARIAN, Biomedical Library, University of California, San Diego. Application deadline extended. Available March 1, 1982 . Assistant Librarian, \$17,412-\$22,284 or Associate Librarian, $\$ 21,288-\$ 30,648$. Under direction of the Biomedical Li brary's Head of Public Services, participates in all reference liaison, instruction and information service, e.g., works at the reference desk assisting patrons in the use of the card catalogs, indexing and abstracting publications and other guides to biomedical literature; advises users on computerized data bases and conducts bibliographic searches on MEDLINE and other systems; prepares exhibits; conducts orientation sessions for users; participates in library instruction of students and health personnel; develops information materials. Responsibilities may also include editing the Biomedical Library Bulletin and will include selecting materials for the general collection in a specific subject area and liaison with the appropriate departments. May share, on a rotating basis, responsibility for providing services in the Medical Center Library, UCSD iibrarians participate in Librarywide planning activities and instruc tional services programs; also expected to be active professionally. Required qualifications: MLS from an ALA-accredited library school experience or education, or both, in the delivery of reference and information services in an academic health sciences library: proficiency in MEDLINE searching is highly desirable; familiarity with medical literature and collection development experience preferred; previous editing experience helpful. Appointment at the Associate level requires well-developed reference skills and substantial previous academic library experience. Applications accepted until February 15,1982 . Submit a letter of application, enclosing a resume and a list of references, 10: Martha L. Bovee, Associate University Librarian, University of California, San Diego, Library C-075-G, La Jolia, California 92093. UCSD is an equal-opportunity/affirmativeaction employer.

REFERENCE LIBRARIAN, Participates in general reader services including reference desk work, collection development, and online searching. Substantial involvement in planning and implementing bibliographic instruction programs with other public services colleagues. Qualifications: Master's degree from ALA-accredited library school, undergraduate major in a social sciences or humanities ciscipline: graduate work or a second master's degree is highly desirable. Strong commitment to public services essential, previous library experience preferred. Salary: $\$ 14,500$ minimum. Send letter 
of application, resume and supporting recommendations by December 31 to Michael S. Freeman, Director of Library Services, The College of Wooster, Wooster, Ohio 44691.

REFERENCE LIBRARIAN, assistant or senior assistant librarian John $M$. Olin Library. Responsibilities: share in staffing busy reference desk in the Olin Library, a research library with over two million volumes, primarily in the humanities and social sciences, serving faculty. graduate students, and undergradutes; participate in other department activities such as user orientation and instruction and answering general correspondence; the secondary assignments, which may include collection development and searching online subject databases, wili vary over time. Qualifications: MLS familiarity with basic bibliographic search techniques; knowledge of at least one foreign language, ability to communicate well with the public and to work calmly under pressure; two to three years of professional academic library public services experience required; background in the humanities or social sciences is preferred. Avail able immediately. Salary: $\$ 13,500$ plus, depending on background experience, and ability. Apply to Carolyn A. Pyhtila. Personnel Director, 235 Olin Library, Cornell University lthaca, NY 14853 Cornell University is an equal-opportunity/affirmative-action employer.

SOCIAL SCIENCE REFERENCE LIBRARIAN. The University of New Orleans, a member of the Louisiana State University System is an urban institution of 16,000 students with a major building ex pansion underway. The University's Earl K. Long Library has a pos. tion open in the Social Sciences Reference Division for an exper enced reference librarian. Primary responsibilities are to provide reference service to faculty, students and the community-at-large and to assist in collection development. Occasional night and weekend duty. Tenure track, faculty status and responsibilities, 12 month contract, 21 days' vacation, benefits. Position will be filled at the assistant or associate level. Salary range $\$ 16,000-\$ 20,000$ based on qualifications and experience Qualifications: minimum 3 years appropriate experience in an academic or research library. Academic background in one of the social sciences and a strong public service orientation required. Experience in online searching and bibliographical instruction helpful. MLS from ALA-accredited li- brary school required. Send letter af application, current resume and names of 3 references to: Donald D. Hendricks, Dean of Library Services, University of New Orleans, Lake Front, New Orleans, LA 70148. Call (504) 286-6556. Applications must be postmarked no later than December 31, 1981. UNO is an equal oppor tunity employer

TECHNICAL SERVICES LIBRARIAN. Corporate Technical Library The Upjohn Company. Reports to the Head, Technical Document Services and has responsibility for Library book and journal acquisi tions in biomedical, pharmaceutical and chemical areas, plus book and journal purchasing services for 14 satellite collections and numerous organizational units utilizing centralized library purchas ing services. Depending on background and interest of qualified applicant, additional responsibilities will also be assumed for at least one of the following: serials control (including serials catalog ing, bindery, serials records, Upjohn holdings and union list development); cataloging (including original cataloging for approximately $5 \%$ of total annual acquisitions, serials cataloging, review of catalog policies and procedures); collection development (including user and departmental collection liaison, book and journal collection weeding and retention policies, microfilm conversion). The de partment also includes 6 clerical staff. Environment: the Corporate Technical Library has a staff of 31 and a collection containing 20,000 books, 30,000 bound journals and 1,300 current periodical subscriptions. The Upjohn Company is located in Kalamazoo, medium-sized southwestern Michigan university city with excellent cultural/recreational opportunities. Qualifications: senior library in formation specialist, BS/BA in science plus MA/MS in library information science (or equivalent of MS in science plus one year information-related experience); plus 3 to 4 years informationrelated experience including 2 or 3 years in one or more of the following technical service areas: serials cataloging, book cataloging (preferably OCLC), acquisitions and collection development for biomedical, pharmaceutical or chemical collections. Supervisory experience preferred. Experience with computer applications to $\mathrm{li}$ brary operations also useful. Salary: $\$ 24,800-\$ 37,200$, depending on experience. Excellent benefits. EEO/AA employer. Apply to Ron Thompson. The Upjohn Company, 7171 Portage Rd., Kalamazoo. MI 49001 .

\section{UNIVERSITY OF ILLINOIS AT CHICAGO CIRCLE}

All of the following positions require an ALA-accredited MLS; ability to promote vigorously information services and instructional programs and to assist users at varying levels of educational background; evidence of interest in professional involvement within academic librarianship; ability to meet university standards in research and publication service commensurate with tenure; other additional requirements as noted.

Assistant Reference Librarian (more than one position may be available): Under the direction of the Reference Librarian, major activities include reference service, library orientation and bibliographic instruction, and computer literature searching. Additional desirable qualifications: previous work experience in reference/information services; experience with or training in computer literature searching.

Assistant Documents Librarian: Under direction of the Documents Librarian, major activities include reference service, library orientation and bibliographic instruction, and computer literature searching. At the UICC Library, documents are housed in a separate Documents Department with a staff of five professionals, three paraprofessionals, two clericals, and student assistants. Additional desirable qualifications: previous work experience in reference/information services, preferably with government publications; coursework in government publications.

Instruction Librarian: Under direction of the Assistant University Librarian (Collection Development and Information Services), incumbent in this newly-created position will develop, implement, coordinate, and evaluate a library-wide user education instruction program. Other minimum qualifications: significant experience in a academic library (or equivalent), including involvement in an instructional program; strong oral and written communication skills.

Salary/Rank/Contract: Salary commensurate with education and experience-beginning salary for librarian with no experience is $\$ 15,000$; rank of assistant professor; 23 days annual vacation, plus 11 paid holidays; 25 days annual sick leave; hospitalization insurance; participation in the State Universities Retirement System.

Application deadline is January 4, 1982. Apply, with supporting resume and names of at least three references, to: Edith D. Balbach, Executive Assistant to the University Librarian, University of Illinois at Chicago Circle, Box 8198, Chicago, Illinois 60680. 

Executive Director for operations and policy formulation, for acquisitions, cataloging/processing, circulation, interlibrary loan, and periodicals units; operation of computerized technical services (OCLC, CLSI, circulation and acquisitions, campus operated data programs) and planning and implementation of online catalogs; planning and consultation with Director's Advisory Group; discharging faculty and community responsibilities. Required: ALA-accredited MLS or equivalent; significant technical services experience in academic or research library, significant administrative experience in technical services, demonstrated abilities in personnel management and oral and written communication. Desirable: additional graduate studies degrees; experience in automated processing in more than one technical services area. Assistant/associate title, faculty rank and salary (minimum $\$ 25,000$ ) subject to qualifications. 12-month contract, tenure track, faculty benefits. Position subject to funding. Send letter, resume and names of 3 to 5 references to $J$. Daniel Vann, Executive Director, Libraries and Learning Resources, University of Wisconsin-Oshkosh, Oshkosh, Wisconsin 54901. Screening to begin December $28,1981$.

UNIVERSITY LIBRARIAN. Ball State University. Applications and nominations are invited for the position of University Librarian. Ball State University has an enrollment of 18,000 and has 98 graduate programs. Faculty and staff number nearly 1,000. The Alexander M. Bracken Library is staffed by 41 professionals and 89 management, office, and technical employees. The book collection is well over the one million mark; current periodical subscriptions approach 5,000. Bracken Library has three branch libraries plus units for archives, government publications, maps, media, music, and special collections. There is also an active library instruction program. The University Librarian serves at the pleasure of the Provost and President at a dean level, reports to the Associate Provost for Instruction and Research, and is responsible for the overall administration of all campus library operations. The person will hold a tenure-line position as a faculty member. Salary is negotiable. The candidate must have an earned doctorate from an accredited institution of higher education, or equivalent education or experience, and a master's degree from an ALA-accredited graduate school of library science. The person must have at least five years of library experience in an academic library including significant experience at an administrative level. The candidate must show a strong commitment to library support for research, teaching, public service, and professional development and have a personal record of scholarly and professional achievement. Experience with extramural funding, management of media materials, and computerized systems is desirable. Applications must be postmarked by January 15, 1982. Send resume, credentials, and the names, addresses, and telephone numbers of three confidential references who may be contacted to: E. Bruce Kirkham, Chairman, University Librarian Search and Screen Committee, Department of English, Ball State University, Muncie, Indiana 47306.

DIRECTOR OF THE LIBRARY. Castleton State College. 130-acre campus in Vermont. 1,200 students. 80 full-time faculty. 70,000 volumes. Library staff: 6. MLS from ALA-accredited library school and 3 to 5 years experience required. Record of professional involvement and knowledge of networking, online systems, and library computer applications highly desirable. Subject master's or Ph.D. preferred. Faculty status, tenure track. Salary in high teens. Send letter of application, resume, and names of 3 references by December 21, 1981, to Rose Marie Beston, Academic Dean, Castleton State College, Castleton, VT 05735.

UNIVERSITY LIBRARIAN. Tulane University. The University Librarian is the chief administrative officer of the Howard-Tilton Library. He reports to the Provost and works closely with the University Senate Library Committee. 
Tulane is a member of the Association of Research Libraries and the Research Libraries Group (RLG). Its libraries contain approximately 1,550,000 bound volumes and about twice that many nonbook items. Some 10,000 periodicals and serials are received regularly. The Howard-Tilton Library staff numbers 40 professional and 78 paraprofessional librarians. The University enrolls 5,500 undergraduate and 2,800 graduate and professional, and 1,900 part-time students in 11 schools and colleges; it offers the Ph.D. in 29 fields. Candidates for the position should have an MLS from an ALA-accredited school. An additional master's degree or a Ph.D. is desirable. The ability to work harmoniously with staff and faculty is essential. Candidates should have a record of successful administration at a senior level, preferably in a library of a size and purpose comparable to Tulane's. Salary will be $\$ 30,000$ or higher depending on professional qualifications or experience. Applications and nominations, accompanied by a resume and a list of 3 references, should be sent by 22 December 1981, to: Donald Pizer, Chairman, Librarian Search Committee, Provost's Office, Gibson Hall, Tulane University, New Orleans, LA 70118. Tulane is an affirmative-action/equal-opportunity employer.

REFERENCE LIBRARIAN AND BIBLIOGRAPHER FOR ENGLISH. University of Cincinnati Libraries. Responsible for building library collections in English, comparative literature, linguistics and journalism and maintaining effective liaison with the faculty of the Department of English and Comparative Literature. Provides general reference and research assistance as well as instruction in library use. Receives general direction from the head, reference/bibliographic services department and consults with the director of collections and information services. The department, with a staff of 10 librarians and 9 support staff plus student assistants, provides reference services and includes government documents; members of the department are also responsible for collection development. The Central Library is a spacious, user-oriented building, 3 years old, housing collections in the humanities, social sciences, business, and education. The University of Cincinnati is a member of the Association of Research Libraries, the Center for Research Libraries, and is the recipient of an NEH challenge grant totalling $\$ 2$ million. The city of Cincinnati is located in the beautiful hills of southwestern Ohio along the Ohio River bordering Kentucky. Qualifications: MLS degree from an ALA-accredited program and a graduate degree in English. Two years of professional experience in an academic library, reading knowledge of one modern European language in addition to English, and ability to communicate clearly, both orally and in writing, required. Must demonstrate potential to meet reappointment and promotion criteria established by librarians. $\$ 15,400$ minimum. Please send resume with cover letter and list of 3 references postmarked by December 31, 1981, to Sharon Tuffendsam, Libraries Personnel Officer, University of Cincinnati Libraries, 640 Central

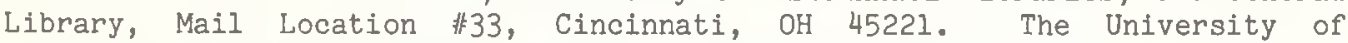
Cincinnati is an affirmative-action/equal-opportunity employer.

HEAD, SERIALS CATALOGING SECTION. M.I.T. Libraries. Under direction of Head, Catalogue Department, will administer all functions of Serials Cataloguing Section; plan for future directions in and establish policies and procedures for serials cataloging; interpret network documentation, and implement new procedures and system modifications; oversee publication of computer-produced holdings list; catalog serials in one or more subject fields. Qualifications: MLS from ALA-accredited library school. 5 years of library experience essential, including knowledge of LC classification and original cataloging of serials. Advanced knowledge of OCLC serial cataloging system essential. Demonstrated supervisory ability. Experience in a research library with significant sci/tech collections preferred. Minimum salary $\$ 18,100$. Submit resume and names of 3 current references, by December 31, 1981, to Search Committee, Libraries, Room 14S-216, M.I.T., Cambridge, MA 02139. An equal-opportunity/affirmative-action employer. 

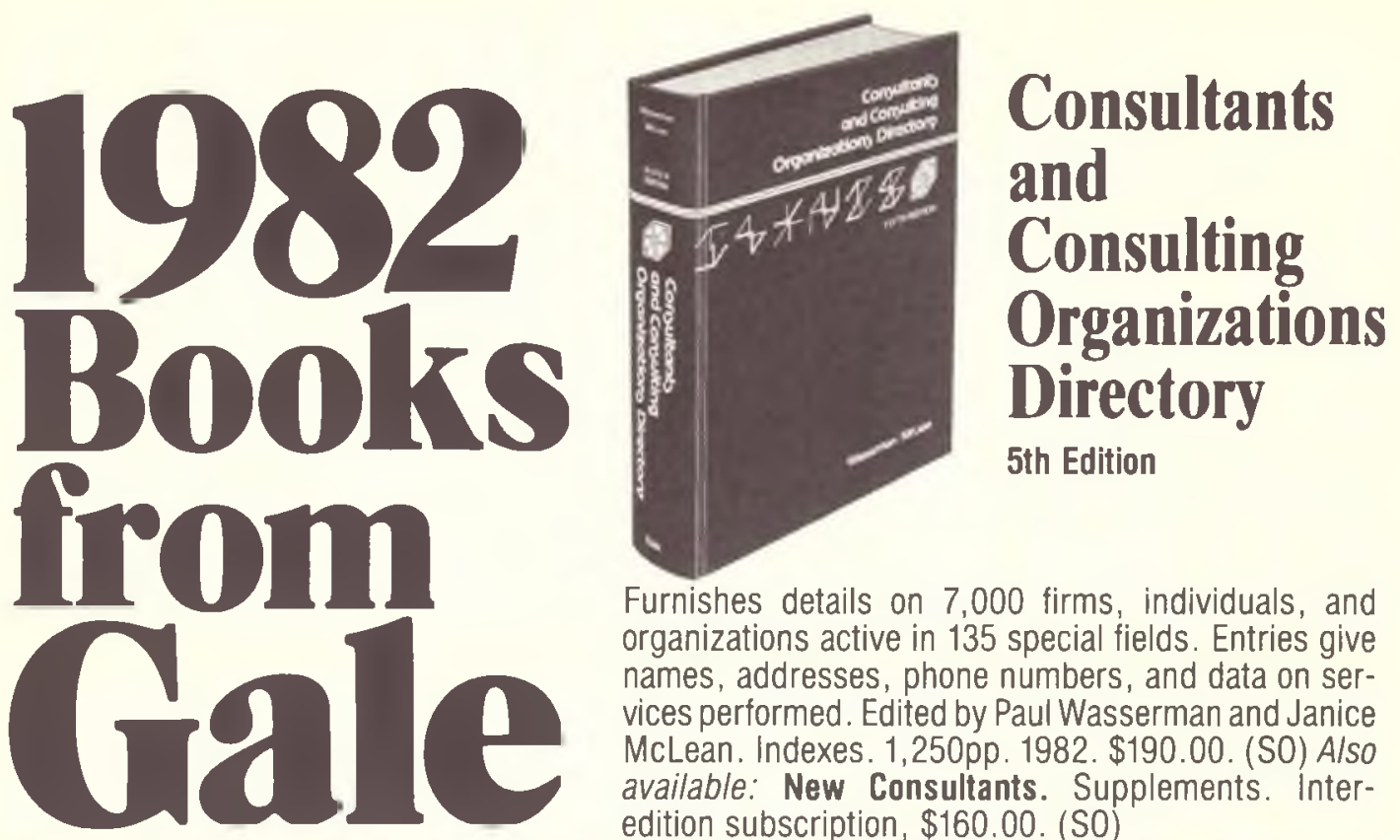

5th Edition

\section{NEW TITLES PUBLISHED AND DISTRIBUTED BY GALE}

\section{All Gale books are sent on 90-day} approval.

(SO) These titles are available at Gale's $5 \%$ standing order discount.

Customers outside the U.S. and Canada add $10 \%$.

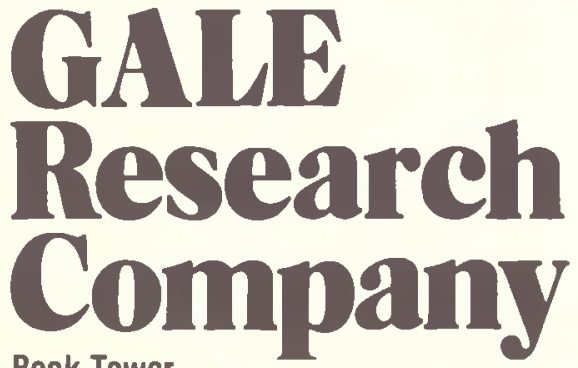

Book Tower

Detroit, MI 48226

\section{International Books in Print 1981-82}

\section{2nd Edition}

Lists over 100,000 available titles in English from publishers in 93 countries other than the U.S. and the U.K. Of special interest is the inclusion of books from little-known thirdworld publishers, public and private organizations, government agencies, and research institutes. Index of publishing houses. 1,250pp. in 2 vols. Published by K. G. Saur, 1982. $\$ 240.00 /$ set. (SO)

\section{Treaties and Alliances of the World 3rd Edition}

Offers worldwide coverage of treaties, alliances, and agreements in force December 31, 1980. Describes international, multilateral, and bilateral treaties and organizations in a wide range of fields, including space, defense, economic cooperation, and environmental protection. Maps. Index. 550pp. Published by Longman, 1981. $\$ 70.00$ (SO)

\section{Storm Data, 1970-1974}

Storm Data, 1975-1979

Each book contains five-year compilations of the Environmental Data Service's official monthly reports of storm activity logged by the U.S. Weather Bureau. Every day of the five-year period is accounted for as storm activity is associated on an hourly basis to particular cities, counties, towns, and villages. Compiled by James A. Ruffner and Frank E. Bair. 1982. $\$ 85.00 /$ vol. (SO) 